SPIRITUAL MODALITIES 



\section{SPIRITUAL MODALITIES}

PRAYER AS RHETORIC AND PERFORMANCE

WILLIAM FITZGERALD

THE PENNSYLVANIA STATE UNIVERSITY PRESS

UNIVERSITY PARK, PENNSYLVANIA 
Library of Congress Cataloging-in-Publication Data

FitzGerald, William, 196I-

Spiritual modalities : prayer as rhetoric and performance / William FitzGerald.

p. $\quad \mathrm{cm}$.

Includes bibliographical references and index.

Summary: "Explores prayer as a rhetorical art, examining situations, strategies, and performative modes of discourse directed to the divine"-Provided by publisher.

ISBN 978-0-27I-05622-7 (cloth : alk. paper)

I. Prayer.

2. Rhetoric.

3. Performance.

I. Title.

BL56o.F58 2012

$204^{\prime} \cdot 3-\mathrm{dc} 23$

2OI2OI77II

Copyright (C) 2012 The Pennsylvania State University All rights reserved

Printed in the United States of America

Published by The Pennsylvania State University Press,

University Park, PA I6802-IOO3

The Pennsylvania State University Press is a member of the Association of American University Presses.

It is the policy of The Pennsylvania State University Press to use acid-free paper. Publications on uncoated stock satisfy the minimum requirements of American National Standard for

Information Sciences-Permanence of Paper for

Printed Library Material, ANsi Z39.48-1992.

This book is printed on Nature's Natural, which contains $30 \%$ post-consumer waste. 
FOR Thomas and Elizabeth 
